\title{
Pemberdayaan Kelompok PKK dalam Pemanfaatan Limbah Kulit Nanas menjadi Sampo di Belik, Pemalang, Jawa Tengah
}

\section{(PKK Group Empowerment in Processing Pineapple Rind into Shampoo in Belik, Pemalang, Central Java)}

\author{
Astrid Noviana1 , Ayu Munti Nilamsari², Rina Yuniarti' ${ }^{1}$, Muhammad Rizqi ${ }^{3}$, Khisnun Baani ${ }^{4}$, \\ Diana Nur Afifah ${ }^{*}$ \\ ${ }^{1}$ Departemen Ilmu Gizi, Fakultas Kedokteran, Universitas Diponegoro, Jl. Prof. Soedarto, Tembalang, Kec. Tembalang, \\ Kota Semarang, Jawa Tengah 50275 \\ 2 Departemen Teknik Kimia, Fakultas Teknik, Universitas Diponegoro, Jl. Prof. Soedarto, Tembalang, Kec. Tembalang, \\ Kota Semarang, Jawa Tengah 50275 \\ ${ }^{3}$ Departemen Sistem Komputer, Fakultas Teknik, Universitas Diponegoro, Jl. Prof. Soedarto, Tembalang, Kec. Tembalang, \\ Kota Semarang, Jawa Tengah 50275 \\ ${ }^{4}$ Departemen Akuntansi, Fakultas Ekonomi dan Bisnis, Universitas Diponegoro, Jl. Prof. Soedarto, Tembalang, \\ Kec. Tembalang, Kota Semarang, Jawa Tengah 50275 \\ *Penulis Korespondensi: d.nurafifah.dna@fk.undip.ac.id \\ Diterima Februari 2019/Disetujui Juli 2019
}

\begin{abstract}
ABSTRAK
Kulit nanas adalah produk samping dari pengolahan nanas di Belik, Pemalang, Jawa Tengah. Kelompok PKK (Pemberdayaan Kesejahteraan Keluarga) difasilitasi untuk mengolah kulit nanas sebagai produk sampingan menjadi sampo untuk mengurangi limbah kulit nanas. Kulit nanas mengandung enzim bromelin yang dapat digunakan sebagai sampo anti ketombe. Tujuan dari kegiatan pengabdian ini adalah untuk meningkatkan kapasitas anggota kelompok PKK dalam mengolah kulit nanas menjadi sampo, sehingga dapat dijual dan mendapatkan penghasilan tambahan dari kegiatan tersebut. Pendekatan yang digunakan dalam sudi ini adalah social engineering, yaitu perpaduan antara pendekatan sosial kemasyarakatan atau pembangunan komunitas (community development) dengan metode pengolahan limbah kulit nanas secara sederhana. Hasil dari kegiatan ini adalah kelompok PKK membentuk Kelompok Usaha Bersama (KUB) Sinar Merpati yang mampu mengolah sampo dari kulit nanas. Shampo dari kulit nanas telah disertifikasi oleh Bupati Belik. Dapat disimpulkan bahwa melalui kegiatan pengabdian kepada masyarakat terjadi peningkatan pengetahuan dan kapasitas dalam mengolah kulit nanas, sehingga memberikan manfaat dalam aspek sosial, ekonomi, dan lingkungan.
\end{abstract}

Kata kunci: limbah kulit nanas, pemberdayaan masyarakat, sampo kulit nanas

\begin{abstract}
Pineapple rind is side product from processing pineapple in Belik, Pemalang, Central Java. The group of Family Welfare Empowerment (known in Indonesia as PKK, Pemberdayaan Kesejahteraan Keluarga) facilitated to processed the pineapple rind as the side product into shampoo to decrease the waste. The rind of pineapple contains of bromelin enzymes that can be used as anti-dandruff shampoo. The purpose of this study was to increase capacity of PKK group to process pineapple rind into shampoo, so group can sell the shampoo and get extra income from the activity. The social engineering approach is used in this study, a combination of a social or community development approach with a simple method of processing pineapple rind. The result of this program, PKK group established KUB Sinar Merpati able to process shampoo from pineapple rind. The shampoo from pineapple rind has been rind certified by the Head of Belik District. It can be concluded that from the community service program increasing knowledge and capacity in processing pineapple rind have contributed benefits in terms of socio-economics and environment.
\end{abstract}

Keywords: community empowerment, pineapple rind, shampoo of pineapple skin

\section{PENDAHULUAN}

Kabupaten Pemalang merupakan daerah penghasil nanas madu terbesar di Jawa Tengah yang memiliki luas panen 1.424 ha. Kecamatan Belik merupakan sentra produksi nanas madu terbesar di Kabupaten Pemalang yang memiliki total luas lahan 474 ha, luas panen 312 ha, dan 
produktivitas sebanyak 18.960 ton/ha (Holtikultura 2013). Nanas madu Belik sebagian diolah menjadi beragam makanan khas Pemalang, seperti selai, stik, dodol, manisan, kripik, dan cocktail nanas. Kegiatan produksi olahan nanas madu tersebut menghasilkan limbah kulit nanas. Menurut Nurhayati (2013) kegiatan pengolahan buah nanas menghasilkan limbah kulit nanas sebesar $27 \%$ dari total produksi buah nanas, sehingga limbah kulit nanas yang dihasilkan mencapai 5,12 ton/ha luas panen, namun limbah tersebut belum diolah dengan baik. Nanas mengandung enzim bromelin termasuk pada kulitnya (Usyan 2012). Enzim bromelin merupakan enzim proteolitik yang bersifat antimikrob, sehingga dapat dimanfaatkan menjadi sampo anti ketombe. Oleh karena itu, perlu upaya untuk mengelola limbah kulit nanas dengan di-manfaatkan menjadi sampo herbal dari kulit nanas (Nurhayati 2013).

Upaya yang dapat ditempuh untuk mengolah limbah kulit nanas menjadi sampo adalah berupa pelatihan kepada ibu-ibu rumah tangga dengan memberdayakan kelompok PKK (Pemberdayaan Kesejahteraan Keluarga). PKK merupakan organisasi yang berperan melaksanakan program yang membangun dan membantu masyarakat dalam mengembangkan potensi yang terdapat di masyarakat (Rumayah 2015).

Studi ini dilakukan di Desa Belik, Pemalang, Jawa Tengah dengan mengedepankan fungsi partisipasi kelompok PKK. Tujuan utamanya adalah untuk transfer ilmu dan melatih kelompok PKK dalam pemanfaatan limbah kulit nanas yang diolah menjadi sampo. Sementara itu tujuan khususnya agar meningkatkan kemandirian kelompok PKK yang terdiri dari ibu rumah tangga dalam mengembangkan usaha pengolahan limbah kulit nanas menjadi sampo serta meningkatkan produktivitas kelompok PKK sehingga mampu memperoleh penghasilan tambahan dari usaha bersama pengolahan nanas madu menjadi sampo.

\section{METODE PELAKSANAAN KEGIATAN}

\section{Waktu dan Lokasi}

Kegiatan ini dilaksanakan pada bulan MaretJuni 2017 di Desa Belik, Kecamatan Belik, Kabupaten Pemalang. Penanggung jawab kegiatan adalah salah satu dosen dari Departemen Ilmu Gizi, Fakultas Kedokteran, Universitas Diponegoro. Pelaksana kegiatan melibatkan lima orang mahasiswa Universitas Diponegoro dari berbagai disiplin ilmu, yakni jurusan Ilmu Gizi, Teknik Kimia, Sistem Komputer, dan Akuntansi. Partisipan pada kegiatan ini adalah PKK Desa Belik sebanyak 21 orang ibu rumah tangga.

\section{Bahan dan Alat}

Pelatihan pengolahan limbah kulit nanas menjadi sampo dilakukan sebanyak 12 kali, dengan 9 kali pelatihan mandiri, sedangkan praktik pemasaran dilakukan setiap satu minggu. Media presentasi berupa proyektor dan LCD digunakan untuk memberikan materi selama pelatihan. Sedangkan bahan yang digunakan untuk membuat sampo kulit nanas terbuat dari sari kulit nanas, air jeruk nipis, larutan Sodium Laurate Sulfate (SLS), Cocamidoprophyl Betaine (Ampitol), parfum aroma buah, dan larutan Etilen Diamine Tetra Asetat (EDTA).

\section{Metode Pelaksanaan}

Program pemberdayaan ini menggunakan pendekatan community development atau pembangunan komunitas dengan dibentuknya program pelatihan secara kelompok. Pendekatan lain yang diterapkan adalah social engineering, yaitu perpaduan antara pendekatan sosial kemasyarakatan atau pembangunan masyarakat (community development) dengan metode pengolahan limbah kulit nanas secara sederhana. Adapun kegiatan-kegiatan yang dilakukan sebagai berikut:

\section{- Survei dan analisis lapangan}

Survei dilakukan di Dusun Kepetek, Desa Belik, Kecamatan Belik, Kabupaten Pemalang untuk mengumpulkan informasi mengenai profil kelompok PKK, profil lingkungan sosial masyarakat sasaran dan pengelolaan limbah kulit nanas sebelum program pengabdian dilaksanakan. Selain itu, dilakukan peninjauan lokasi untuk pelaksanaan sosialisasi dan pelatihan, melakukan diskusi dengan mitra, melakukan perizinan dengan pemerintah setempat, serta koordinasi rencana pelaksanaan kegiatan dengan mitra dan pemerintah setempat guna memeroleh dukungan dan kepercayaan masyarakat sasaran.

\section{- Sosialisasi program dan penyuluhan}

Sosialisasi dilaksanakan dengan mengundang ibu-ibu rumah tangga dari masing-masing Rukun Warga (RW). Sosialisasi berupa penyampaian informasi mengenai tujuan pengabdian, rencana kegiatan, dan teknis pelatihan pengolahan 
limbah kulit nanas menjadi sampo. Penyuluhan berisi penjelasan mengenai teknis pembuatan sampo dari limbah kulit nanas dan penyampaian materi pentingnya keterampilan kewirausahaan pada ibu rumah tangga oleh mahasiswa. Kesadaran akan pentingnya kewirausahaan harus ditingkatkan dan didukung mengingat hal ini akan sangt membantu perekonomian keluarga (Rohmani et al. 2018), sehingga diharapkan melalui usaha pengolahan kulit nanas menjadi sampo ini dapat meningkatkan pendapatan tambahan keluarga.

\section{- Pelatihan}

Kegiatan pelatihan dilakukan dalam tiga tahap, pelatihan pertama dilakukan pada acara sosialisasi dan penyuluhan, pelatihan tahap selanjutnya dilakukan oleh kelompok PKK dengan didampingi mahasiswa, dan pelatihan tahap ketiga dilakukan secara mandiri oleh kelompok PKK. Pelatihan tahap pertama bertujuan untuk memberikan keterampilan mengenai teknis pembuatan sampo dari kulit nanas secara partisipatif dengan melibatkan ibu rumah tangga yang hadir di acara sosialisasi. Pelatihan tahap kedua bertujuan untuk melihat penerapan teknis pembuatan sampo kulit nanas oleh ibu-ibu rumah tangga dan mengetahui kendala yang dihadapi pada saat mengolah kulit nanas menjadi sampo. Sementara itu pelatihan tahap ketiga bertujuan untuk melatih kemandirian ibu-ibu rumah tangga dalam mengolah kulit nanas menjadi sampo serta memantau perkembangan usaha pengolahan kulit nanas menjadi sampo tersebut.

\section{- Monitoring dan evaluasi}

Monitoring bertujuan untuk melihat perkembangan kondisi masyarakat dan lingkungan setelah program pengabdian dilaksanakan. Monitoring dilakukan dengan mengawasi jalannya kegiatan selama program pengabdian berlangsung. Monitoring meliputi tiga aspek,

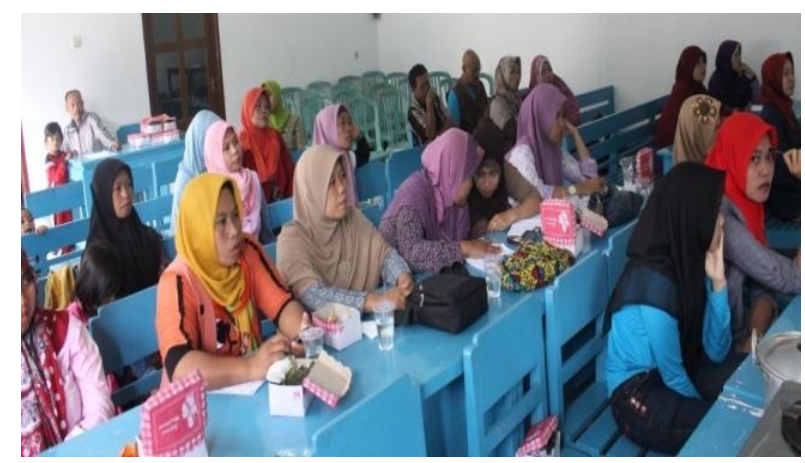

yakni antusiasme dan konsistensi masyarakat dalam melaksanakan program, kemampuan masyarakat dalam mengolah, memperkenalkan, dan memasarkan sampo kulit nanas serta melihat potensi keberlangsungan usaha pengolahan kulit nanas menjadi sampo setelah program selesai dilaksanakan.

Evaluasi bertujuan untuk menilai dampak pelaksanaan program, baik dari segi lingkungan, sosial, dan ekonomi. Dampak lingkungan berupa berkurangnya limbah kulit nanas, dampak sosial berupa peningkatan keterampilan dan produktivitas masyarakat sasaran. Sementara itu dampak ekonomi dilihat dari peningkatan pendapatan ibu rumah tangga dari hasil penjualan sampo kulit nanas.

\section{HASIL DAN PEMBAHASAN}

\section{Sosialisasi Program dan Penyuluhan}

Sosialisasi dilaksanakan di Balai Pertemuan PKK Desa Belik, Kecamatan Belik, Kabupaten Pemalang. Sasaran sosialisasi adalah ibu rumah tangga berjumlah 21 orang perwakilan dari tujuh RW, dan setiap RW diwakili 3 orang ibu rumah tangga. Ibu-ibu rumah tangga yang hadir merupakan anggota yang berperan aktif dalam kegiatan PKK. Selain itu, sosialisasi dihadiri oleh 17 orang pengurus $\mathrm{PKK}, 10$ orang perangkat desa, Bapak Kepala Desa Belik beserta Ibu, serta dua orang dari Dinas Lingkungan Hidup Kabupaten Pemalang.

Kegiatan sosialisasi diikuti dengan antusias oleh ibu-ibu rumah tangga dan para tamu undangan seperti terlihat pada Gambar 1. Kepada Desa Belik dan Perwakilan dari Dinas Lingkungan Hidup memberikan sambutan dalam acara sosialisasi. Kepala desa memberikan dukungan terhadap kegiatan pengabdian ini dan berharap pengolahan kulit nanas dapat berlangsung dengan baik dan berlanjut meskipun pelatihan telah selesai dilaksanakan. Sementara

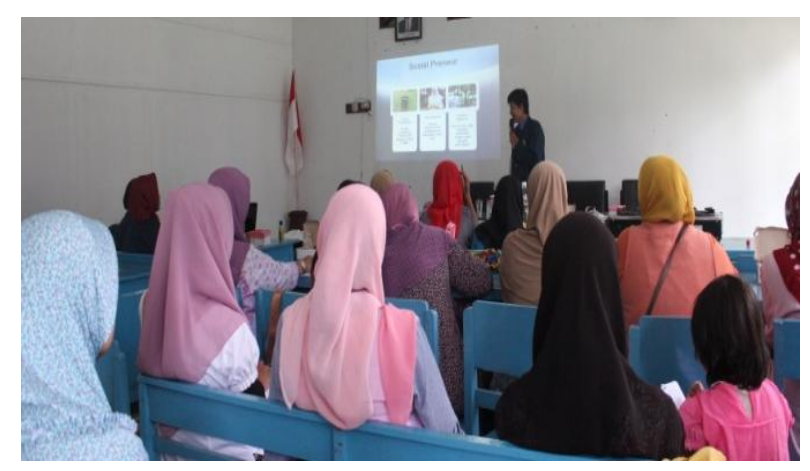

Gambar 1 Sosialisasi pelatihan pembuatan sampo kulit nanas. 
itu, perwakilan Dinas Lingkungan Hidup menyatakan bahwa pemerintah bersedia melakukan pembinaan dan pendampingan kepada masyarakat terkait pengelolaan lingkungan, dalam hal ini pengolahan limbah kulit nanas.

Selain sambutan dari pihak terkait, disampaikan pula mengenai tujuan program pengabdian, materi kewirausahaan, teknis pengolahan kulit nanas menjadi sampo, dan menyusun rencana kegiatan bersama dengan ibuibu rumah tangga. Setelah itu, ibu-ibu rumah tangga yang hadir dibagi dalam bentuk kelompok yang terdiri dari 7-10 orang untuk mempermudah pelaksanaan pelatihan pendampingan (Gambar 2). Kelompok yang sudah terbentuk disebut sebagai kelompok PKK pengolah limbah kulit nanas.

Gambar 2 menunjukkan bahwa pemerintah terlibat dalam kegiatan pengolahan kulit nanas menjadi sampo. Pemerintah desa atau kepala desa berperan sebagai animasi sosial dan pemberi dukungan. Animasi sosial maksudnya kepala desa memberikan bimbingan, pengarahan, dan mengajak masyarakat berpartisipasi dalam pembangunan desa. Sedangkan, pemberi dukungan maksudnya pemerintah berperan dalam pemantauan dan koordinasi untuk mendorong keberhasilan program (Rukminto 2008). Sementara itu Dinas Lingkungan Hidup berperan melaksanakan tugas pokoknya dalam pelestarian dan pemulihan lingkungan.

Gambar 3 menunjukkan kegiatan pembagian kelompok PKK. Pelatihan dilakukan berkelompok karena ibu-ibu PKK belum berpengalaman dalam mengolah sampo kulit nanas sehingga dikhawatirkan timbul rasa tidak percaya diri. Terbentuknya kelompok tersebut akan menumbuhkan kesadaran dan kemampuan tiap anggota untuk memanfaatkan potensi yang mereka miliki (Rahayu 2013). Selain itu, ibu-ibu PKK terlibat secara langsung dalam pembagian kelompok. Hal ini menunjukkan bahwa ibu-ibu PKK ikut berpartisipasi aktif dalam program pengabdian. Partisipasi ibu-ibu PKK membuat mereka memiliki perhatian terhadap permasalahan yang ada di lingkungannya dan memiliki kepercayaan diri bahwa mereka dapat berkontribusi untuk ikut mengatasinya (Kristiniati \& Choiriyah 2014).

\section{Pelatihan Pengolahan Limbah Kulit Nanas Menjadi Sampo Secara Partisipatif}

Pelatihan partisipatif merupakan pelatihan tahap pertama yang dilakukan pada acara sosialisasi dan penyuluhan. Ibu-ibu rumah tangga diajak untuk terlibat dalam proses pengolahan sampo dari kulit nanas setelah diberikan penjelasan mengenai panduan teknis pengolahannya oleh mahasiswa. Saat pelatihan berlangsung, ibuibu rumah tangga antusias dalam mengolah kulit nanas menjadi sampo serta aktif bertanya mengenai prosedur pembuatan, daya simpan, maupun efek dari pemakaian sampo kulit nanas. Pelaksanaan pelatihan partisipatif terlihat pada Gambar 3.

Antusiasme ibu-ibu rumah tangga menunjukkan bahwa mereka tertarik dan mempunyai keinginan untuk mampu mengolah limbah kulit nanas menjadi sampo. Selain itu, mereka memiliki kesadaran untuk mengatasi permasalahan limbah kulit nanas yang sebelumnya tidak dikelola dengan baik. Partisipasi diartikan sebagai keterlibatan secara sadar dan spontan disertai dengan tanggung jawab terhadap

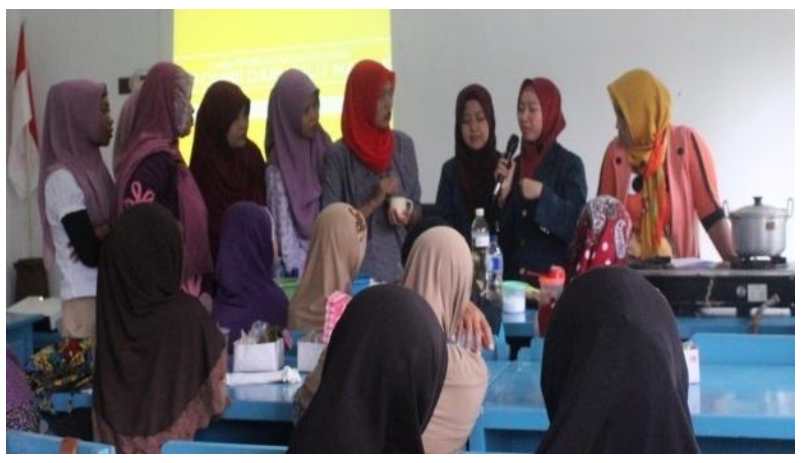

Gambar 2 Pembagian kelompok PKK
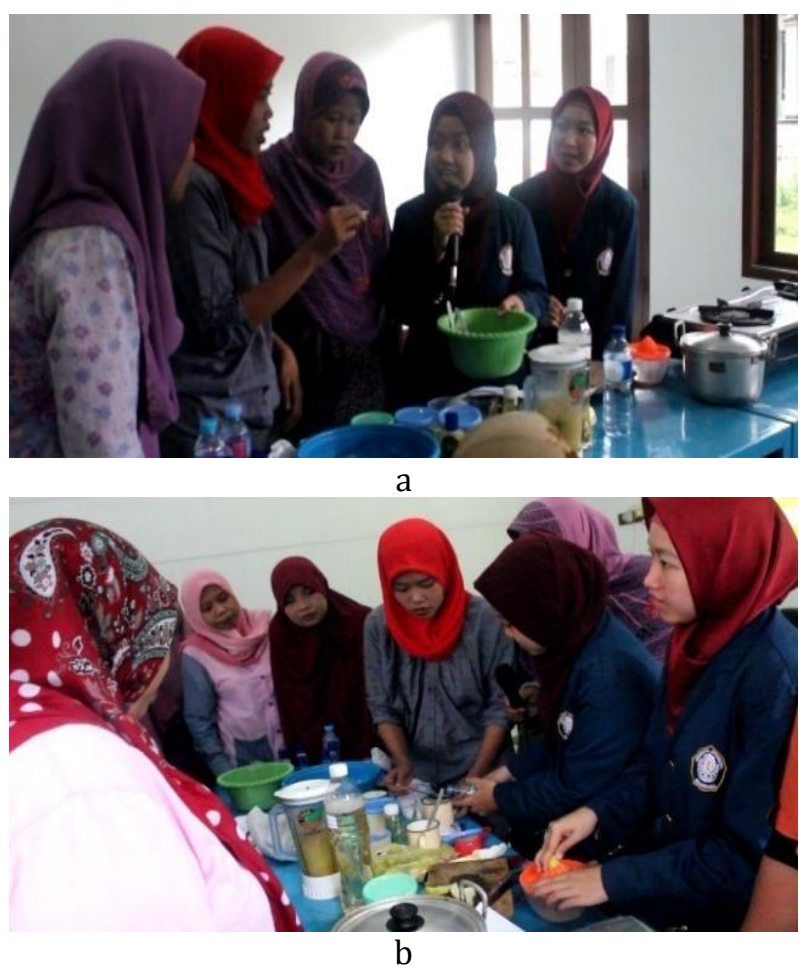

Gambar 3 a dan b Pelaksanaan pelatihan partisipatif. 
kepentingan kelompok untuk mencapai tujuan bersama (Arif 2012).

\section{Pelatihan Pengolahan Limbah Kulit Nanas Menjadi Sampo dengan Pendampingan}

Pelatihan pendampingan dilaksanakan di rumah Kepada Desa Belik pada 23 April 2017 pukul 10:00-14:00 WIB. Pelatihan dihadiri oleh tujuh orang ibu rumah tangga dan lima orang mahasiswa. Pemahaman kelompok PKK sebelum dilaksanakan pelatihan pendampingan masih kurang, sehingga perlu dibimbing dan didampingi tim pelatih. Produk yang dihasilkan dari pelatihan pendampingan dimanfaatkan dalam skala rumah tangga oleh kelompok PKK dan juga dibagikan kepada tetangga untuk memberikan tanggapan mengenai produk sampo kulit nanas yang dihasilkan.

Pelatihan pendampingan merupakan tindak lanjut dari pelatihan sebelumnya, di mana ibu-ibu rumah tangga dilatih untuk mengolah sampo dari kulit nanas secara kelompok (Gambar 4). Tahap ini mahasiswa berperan sebagai pendamping untuk mengawasi jalannya pelatihan dan mengingatkan kelompok PKK apabila terdapat kesalahan pada saat pelatihan. Selain itu, pada tahap ini juga dilakukan diskusi mengenai kendala yang ditemui pada saat pelatihan dilaksanakan. Kegiatan pendampingan juga melatih ibu-ibu PKK untuk mampu mengidentifikasi kebutuhan kelompok selama program berlangsung dan mencari solusi untuk memenuhi kebutuhan tersebut (Himawan et al. 2012)

\section{Pelatihan Pengolahan Limbah Kulit Nanas Menjadi Sampo Secara Mandiri}

Pelatihan mandiri adalah pelatihan tahap akhir yang dilakukan ketika kelompok PKK mampu membuat sampo kulit nanas dengan benar, namun masih dilakukan pemantauan. Pelatihan mandiri dilaksanakan secara rutin dan diikuti oleh semua anggota kelompok. Pelatihan mandiri dilakukan sebanyak sembilan kali selama bulan Mei-Juni 2017.

Kemandirian merupakan salah satu konsep pemberdayaan dalam wacana pembangunan. Kemandirian kelompok PKK terbentuk setelah dilakukan pelatihan mandiri. Selama melakukan pelatihan mandiri ibu-ibu PKK menghasilkan produk sampo kulit nanas dengan kualitas yang sesuai dengan yang diharapkan, yakni berwarna kuning muda, tembus pandang, tekstur kental, dan beraroma khas nanas (Gambar 5). Produk sampo hasil pelatihan mandiri sudah mulai dipasarkan di toko oleh-oleh dan di perkantoran.

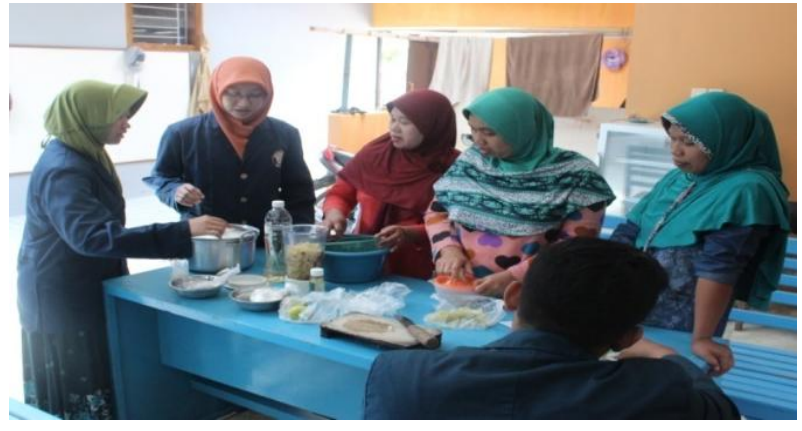

a

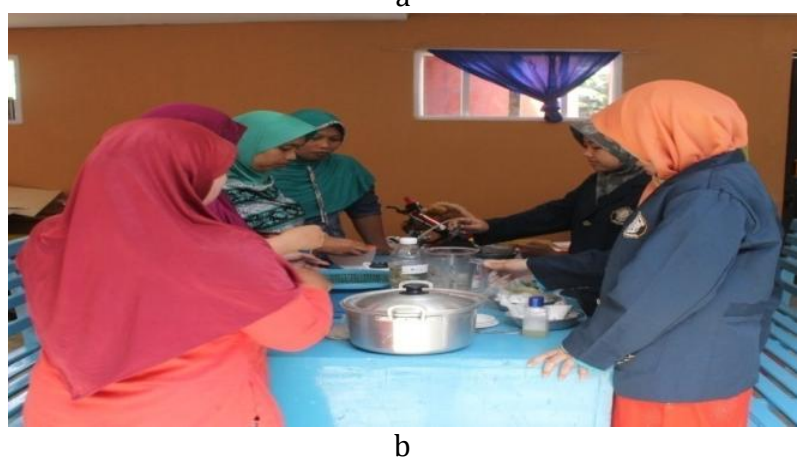

Gambar 4 a dan b Pelatihan pendampingan.

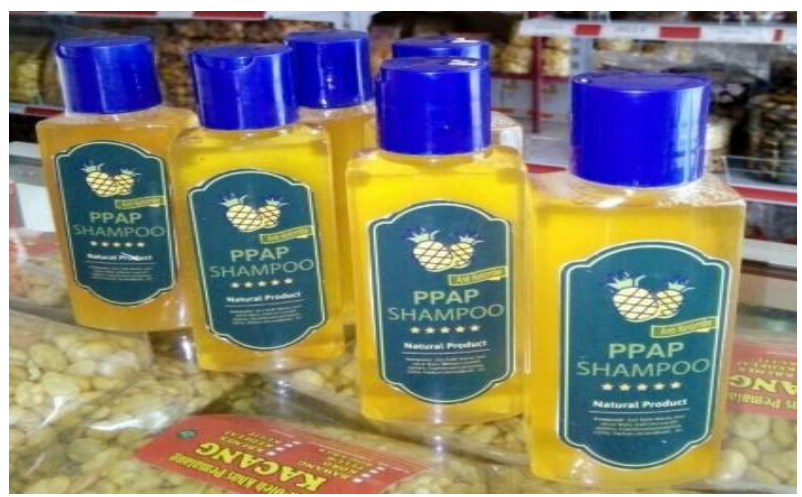

Gambar 5 Pemasaran sampo di toko oleh-oleh.

\section{Pembentukan Kelompok Usaha Bersama}

Kelompok PKK yang telah mampu mengolah sampo dari kulit nanas secara mandiri kemudian membentuk Kelompok Usaha Bersama (KUB). Tujuan pembentukan KUB adalah supaya kelompok PKK diakui secara formal dan sebagai langkah awal pembentukan Usaha Mikro Kecil dan Menengah (UMKM) (Rahayu 2013). Pengajuan surat KUB dilakukan tanggal 12 April 2017 di kantor kelurahan Desa Belik. Nama yang diberikan pada KUB adalah Sinar Merpati. KUB Sinar Merpati mempunyai struktur organisasi seperti terlihat pada Gambar 6.

Pembentukan KUB didasarkan pada pembangunan masyarakat/Community Development (CD). Dengan demikian, anggota KUB memiliki kesadaran bahwa mereka anggota suatu komunitas yang memiliki struktur, pola perilaku, aturan, dan tujuan sama. Selain itu, diperlukan 


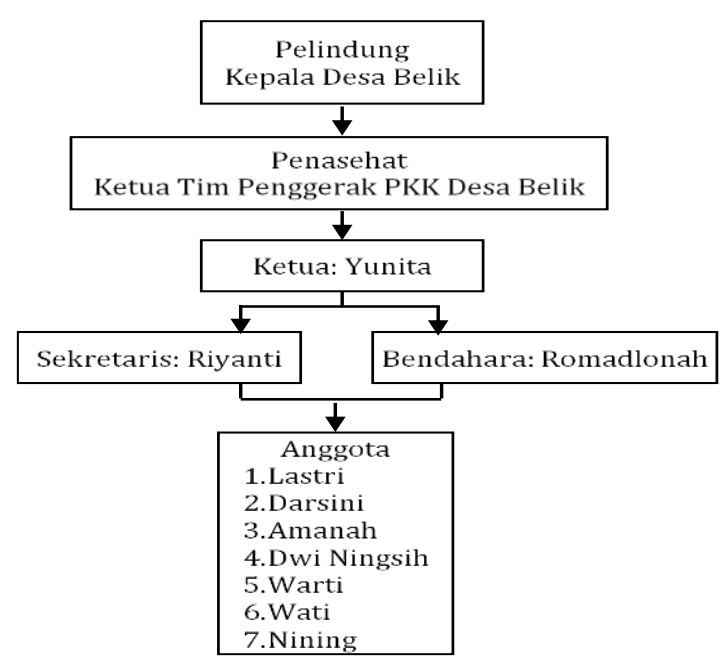

Gambar 6 Struktur organisasi kelompok usaha bersama Sinar Merati.

interaksi, komunikasi, dan kepatuhan anggota terhadap norma yang mengatur hubungan antar anggota kelompok untuk mencapai kepentingan bersama.

\section{Perbaikan Sistem Pengelolaan Limbah Kulit Nanas}

Limbah kulit nanas sebelumnya dibuang di tempat pembuangan sampah dan sungai. Setelah terbentuk KUB, limbah kulit nanas yang dihasilkan dari pedagang maupun pengolah makanan berbahan nanas dikumpulkan kemudian diambil oleh KUB untuk diolah menjadi sampo. Dengan demikian, jumlah limbah kulit nanas yang dibuang menjadi berkurang. Koordinasi secara langsung antara pihak penghasil limbah kulit nanas dan KUB membuat sistem pengelolaan limbah kulit nanas menjadi lebih baik. Hal tersebut menunjukkan bahwa salah satu tujuan program pengabdian masyarakat telah tercapai, yakni meningkatnya partisipasi masyarakat dalam pemeliharaan lingkungan (Kristiniati \& Choiriyah 2014).

\section{Peningkatan Produktivitas Ibu Rumah Tangga}

Pengolahan limbah kulit nanas menjadi sampo menjadi kegiatan yang positif bagi kelompok PKK yang terdiri dari ibu-ibu rumah tangga yang tidak bekerja. Pelatihan pengolahan limbah kulit nanas menjadi sampo meningkatkan keterampilan ibu rumah tangga dalam mengolah limbah kulit nanas yang sebelumnya hanya dibuang menjadi produk sampo yang memiliki nilai tambah (added value). Dengan demikian, program pengabdian mampu meningkatkan produktivitas ibu-ibu rumah tangga sehingga tercapai salah satu tujuan pengabdian berupa meningkatkan komunitas pedesaan (Kristiniati \& Choiriyah 2014).

\section{Peningkatan Pendapatan Ibu Rumah Tangga}

Produk sampo yang dihasilkan dari limbah kulit nanas tidak hanya dimanfaatkan dalam skala rumah tangga, tetapi dijual di toko oleholeh dan dipasarkan di perkantoran sekitar Desa Belik, Kabupaten Pemalang. Hasil penjualan sampo kulit nanas digunakan untuk reproduksi sampo kulit nanas dan laba yang didapatkan dibagikan kepada ibu rumah tangga. Adanya kegiatan pengolahan kulit nanas menjadi sampo dapat menjadi sumber pendapatan ibu rumah tangga. Kegiatan pengabdian berhasil mendayagunakan potensi yang ada, yaitu limbah kulit nanas secara optimal untuk kemakmuran dan kesejahteraan bersama (Kristiniati \& Choiriyah 2014).

\section{SIMPULAN}

Simpulan yang dapat diuraikan berdasarkan hasil pelaksanaan kegiatan pemberdayaan masyarakat tentang pengolahan limbah kulit nanas menjadi sampo adalah pemberdayaan ibuibu kelompok PKK dalam memanfaatkan limbah kulit nanas menjadi sampo dilakukan melalui tiga tahap, yaitu pemberikan pengetahuan mengenai teknis pembuatan sampo, pelatihan, dan monitoring evaluasi. Terbentuknya Kelompok Usaha Bersama (KUB) Sinar Merpati yang terdiri dari Kelompok PKK yang telah mampu mengolah limbah kulit nanas menjadi sampo secara mandiri. Kegiatan pemberdayaan ibu-ibu kelompok PKK mempunyai dampak berupa perbaikan sistem pengelolaan limbah kulit nanas, peningkatan produktivitas, dan peningkatan pendapatan ibu-ibu kelompok PKK yang tidak bekerja.

\section{UCAPAN TERIMA KASIH}

Ucapan terima kasih disampaikan kepada kelima mahasiswa Universitas Diponegoro yang terlibat, Ibu-ibu PKK Desa Belik, Kepala Desa Belik, dan ibu serta Dinas Lingkungan Hidup Kabupaten Pemalang, Jawa Tengah yang telah berpartisipasi dalam program pemberdayaan masyarakat melalui pemberdayaan kelompok PKK dalam pemanfaatan limbah kulit nanas menjadi sampo di Desa Belik ini. 


\section{DAFTAR PUSTAKA}

Arif S. 2012. Partisipasi Warga dalam pembangunan dan Demokrasi. Jakarta (ID): Averroes Press.

Himawan I, Hardjo B, Hadi I, Budiono P. 2012. Partisipasi Masyarakat dalam Proses Pembangunan di Kecamatan Kemiling. Dalam: Seminar hasil-hasil penelitian dan pengabdian kepada masyarakat- Dies Natalis Fisip Unila tahun 2012. Lampung (ID): Universitas Lampung. (p. 44).

Holtikultura H. 2013. Profil Nanas Kabupaten Pemalang, Jawa Tengah. In: Direktorat Jendral Holtikultura.

http//horti.pertanian.go.id/node/10.

Kristiniati R, Choiriyah lU. 2014. Partisipasi masyarakat dalam pelaksanaan Program Nasional Pemberdayaan Masyarakat Mandiri Perkotaan (PNPM-MP) di Desa Bligo Kabupaten Sidoarjo. Jurnal Kebijakan \& Manajemen Publik. 02(02): 206-207. https://doi.org/10.21070/jkmp.v2i2.439

Nurhayati N. 2013. Penampilan ayam pedaging yang mengonsumsi pakan mengandung kulit nanas disuplementasi dengan yogurt. Agripet.
13(02): 15-20. https://doi.org/10.17969/ agripet.v13i2.814

Rahayu H. 2013. Kebijakan penanganan kemiskinan melalui Kelompok Usaha Bersama (KUBE). Informasi. 18(02): 117-132.

Rohmani S, Yugatama A, Prihapsara F. 2018. Inovasi Minuman Sehat Berbahan Kedelai dalam Upaya Pemberdayaan Masyarakat melalui Wirausaha di Kabupaten Sukoharjo. Agro Kreatif Jurnal Ilmuah Pengabdian kepada Masyarakat. 4(2): 68-74. https://doi.org/ 10.29244/agrokreatif.4.1.68-74

Rukminto AI. 2008. Intervensi Komunitas Pengembangan Masyarakat Sebagai Upaya Pemberdayaan Masyarakat. Jakarta (ID): PT. Raja Grafindo Persada.

Rumayah. 2015. Pelaksanaan Program Pemberdayaan dan Kesejahteraan Keluarga (PKK) dalam Pemberdayaan Masyaraka di Desa Malinau, Kecamatan Malinau. Jurnal Pemerintahan Integratif. 3(02): 323-335.

Usyan BG. 2012. Pemanfaatan Kulit Nanas menjadi Sampo Alternatif Pembersih Rambut dan Kulit Kepala. Riau (ID): SMA IT Mutiara. 